\title{
Gender-Related Persecution as a Basis for Refugee Status: The Emergence of an International Norm
}

\author{
Stephanie Kuttner
}

\begin{abstract}
In 1993, Canada was the first country to formally open its doors to refugees fleeing gender-related persecution. While the timing of Canada's move may have been motivated by domestic politics, it was also tied to an international process through which the human rights of women and gender-related persecution had become politically relevant issues. This article investigates the emergence of an international norm accepting gender-related persecution as a basis for refugee status. It begins with an overview of developments on the matter in other jurisdictions and reveals the role Canada played by taking a first step. The article also reveals the process through which domestic, transnational and international actors converged to put the issue of gender-related persecution on the international agenda.
\end{abstract}

\section{Précis}

En 1993, le Canada a été le premier pays à ouvrir officiellement ses frontières aux réfugiés fuyant une persécution fondée sur le sexage. Le moment choisi pour poser cegeste a certainement été motivé, de la part du Canada, par des considérations domestiques, mais il est aussi lié à un processus international à travers lequel les droits des femmes et la persécution fondée sur le sexage sont devenus des questions politiques d'importance. Le présent article étudie l'émergence d'une norme internationale reconnaissant la persécution fondée sur le sexage comme un critère pour l'obtention du statut de réfugié. Il s'amorce sur un survol des développements sur la question dans d'autres juridictions et révèle le rôle joué par le Canada par le seul fait defaire les premiers pas en la matière. Le

Stephanie Kuttner is a Ph.D. candidate, International Relations, St. Anthony's College, University of Oxford, Oxford, United Kingdom. présent article révèle aussi le processus ayant amené les intervenants domestiques, supranationaux et internationaux à une convergence de vue sur l'introduction de la question de la persécution fondée sur le sexage à l'ordre du jour international.

In 1993, with the release of the Guidelines on Women Refugee Claimants Fearing Gender-Related Persecution, ${ }^{1}$ Canada took a big step forward in legitimizing the refugee claims of women who face gender-related persecution. The United States and Australia subsequently followed suit by issuing similar policy papers in 1995 and 1996 respectively. ${ }^{2}$ Though in a somewhat more piecemeal fashion, several European countries appear to be moving in a similar direction. Thus, while Canada, the United States, and Australia cannot be said to represent the protection standards of all countries, their policies point to the general direction of normative developments internationally. ${ }^{3}$ These expansive developments are particularly notable given the general period of retrenchment in refugee policy. ${ }^{4}$

National refugee policy offers an indication of the extent to which a state is willing to act on its international human rights promises. The criteria for granting refugee status set out those rights which are considered so fundamental that their violation is a sufficient basis for granting asylum to a foreign national. When such rights are violated, states are willing to risk offending a fellow sovereign state by granting refugee status to one of its nationals and thus implicitly, if not explicitly, criticizing the other's internal affairs. The case of refugee claims based on gender-related persecution offers the possibility of examining the strength of states' commitment to the human rights of women.
This article investigates the emergence of an international norm accepting gender-related persecution as a basis for refugee status. To explain the genesis of such a norm, it looks for causal connections in the interplay between "bottom-up" factors of domestic interest groups and societal norms; "top-down" factors of the international institutions of law, conferencing, and the United Nations system; and "transnational" factors of principled issue networks 5 and experts operating within the international refugee system.

\section{Overview of International Developments}

It is difficult to establish exactly how the "gender" problem in refugee law was initially identified. In 1984, the European Parliament passed a resolution calling upon states to recognize that women who face harsh or inhuman treatment for having transgressed their society's social mores constitute a "particular social group" within the meaning of the definition of refugee in the UN Refugee Convention. ${ }^{6}$ The following year, the Executive Committee of the United Nations High Commissioner for Refugees (UNHCR) passed a similar resolution. ${ }^{7}$ The international community was thereby made aware of this aspect of the gender problem in refugee law.

By 1991, the Canadian Immigration and Refugee Board (IRB) had set up a Working Group on Refugee Women Claimants comprised of IRB Members and staff, refugee women, NGOs, UNHCR representatives and academic experts. This group pressed for the development of Canadian gender guidelines raising both substantive and procedural issues needing to be addressed. In the early 1990s, a series of controversial IRB decisions rejecting gender-related persecution claims

Refuge, Vol. 16, No. 4 (October 1997) 
brought the issue into the public eye. ${ }^{8}$ Refugee and women's rights advocates managed to bring significant media attention to these decisions and to the systemic gender-bias within the refugee determination process as it then operated. There was a significant public outcry which put politicians under the spotlight; their initial rejection of the need for change was badly received. ${ }^{9}$ Political pressure increased, and eventually a new official position was taken to change national criteria such that gender-related persecution claims became an accepted basis on which to grant refugee status within the Canadian system.

On International Women's Day in 1993, the IRB released the Guidelines on Women Refugee Claimants Fearing Gender-Related Persecution. According to the IRB Chairperson, the Guidelines' drafters drew on international aids to interpretation including the UNHCR Handbook, various UNHCR statements and initiatives on refugee women, and jurisprudence from other jurisdictions. ${ }^{10}$ Academic articles and other authorities were also relied upon. Thus, the Guidelines can be said to have emerged from a complex process of interaction with domestic Canadian groups, an international institution (UNHCR), international law (international human rights standards and jurisprudence from other jurisdictions) and transnational issue networks (academic articles and reports of international human rights NGOs).

How were refugee advocates' claims of injustice able to garner such popular support and ultimately lead to change in the national refugee determination systems? Fundamental principles of equality and non-discrimination run through all international human rights treaties and particularly those relevant to women's human rights. In Canada, such principles have been embodied in the cornerstone of the domestic legal and political system: the Constitution. In particular, the Charter of Rights and Freedoms ${ }^{11}$ includes specific sexual equality provisions. As well, all provincial human rights codes have simi- lar provisions. In the Canadian debate, it is possible to see how fundamental legal norms of equality and non-discrimination, and some preliminary developments on the issue of genderrelated persecution at the international level, were used by advocates to strengthen their position. ${ }^{12}$

Canadian advocates for the acceptance of gender-related persecution as a basis for refugee status were therefore able to refer to strongly entrenched principles of equality and non-discrimination in articulating their position. It was not viable for officials to respond by claiming that discrimination was a legitimate or intentional policy choice. Instead, they argued either that the situation did not in fact transgress these principles, that other policy considerations of population control came into play, or that to introduce such a new norm would transgress another fundamental principle-avoiding cultural imperialism. Given the evidence to the contrary, it was difficult to maintain that genderbias in the refugee determination procedures was not a systemic problem. Floodgates arguments were trumped by the fundamental principles of equality and non-discrimination which also superseded claims of cultural imperialism.

With their release of official policy guidelines, Canada, the United States and Australia have taken the lead in articulating clear standards for assessing gender-related persecution claims. It is more difficult to assess the situation in countries which have not published comprehensive official policy documents on gender-related persecution as a basis for refugee status. How the UN Refugee Convention definition of a refugee is reflected in national legislation and jurisprudential interpretation of its provisions vary from country to country. Differences in national refugee determination procedures also affect outcomes of claims based on gender-related persecution. However, it is possible to discern a piecemeal elaboration of standards for accepting gender-related persecution as a basis for refugee status in the scattered judi- cial decisions and cursory policy statements of certain countries. In an incremental fashion, there has been an ongoing evolution in the concepts of "persecution," "state agency," and criteria for "membership in a particular social group" in international law.

A 1994 comparative study of the policy and jurisprudence relating to female asylum seekers by the Dutch Refugee Council found that the Netherlands, Germany, and France recognize sexual violence as a form of persecution. ${ }^{13}$ In 1996, the Minister of State for the Home Office made a public statement to the effect that genderspecific forms of harm such as forced abortion, sterilization and genital mutilation constitute torture and can therefore be the basis for granting refugee status in the United Kingdom. Instructions to asylum case workers detailing gender-specific practices that constitute torture were subsequently issued. ${ }^{14}$

Except for Germany in which it has been accepted that gender can be a ground of persecution, ${ }^{15}$ European Union countries have not tended to accept claims of persecution for reasons of gender alone. Recent amendments to the Swedish Aliens Act ${ }^{16}$ lowers the protection standard available to claimants facing gender-based persecution designating them as "persons in need of protection" rather than refugees under the UN Refugee Convention. Most other European Union countries take a restrictive interpretation of the Convention ground of membership in a particular social group. ${ }^{17}$ The criteria elaborated in Dutch jurisprudence that refugee claimants be shown to have been individually "singled-out" for persecution is problematic for all cases based on social group persecution. The "singled-out" criteria adds to the difficulties of women who base their claims on a gender-defined particular social group. ${ }^{18}$ However, German and French refugee determination officials have accepted cases of women fleeing persecution for the transgression of social mores as belonging to a particular social group. ${ }^{19}$ Norway has officially adopted the 
UNHCR Executive Committee Conclusion No. 39 recommending that women who face retribution for the transgression of social mores be considered members of a particular social group..$^{20}$ Thus, while in general, gender alone may not be sufficient to establish a particular social group in European Union countries (and Sweden offers a lower protection standard), there has been significant progress made in the recognition of social groups in which gender is one of the determining factors.

\section{Internationalizing the Campaign for Change}

How was the campaign to change national refugee determination systems internationalized? Amidst the tangled web of interactions that constitutes international relations, three significant "institutional spaces" can be identified where campaigns for redressing gender-bias in refugee regimes were focused. These are international conferences where transnational issuenetworks converged to put pressure on states; the UNHCR where a community of refugee experts could encourage the adoption of policies favouring gender claims; and the international legal process through which new standards are elaborated.

In the international campaign to establish gender-based persecution as a ground for refugee status, women's rights, human rights and refugee rights networks converged. They combined efforts to influence the informational and political contexts in which states took positions at international conferences on women and on human rights at Nairobi in 1985, Vienna in 1993 and Beijing in 1995. Their efforts on the broad issues of women's human rights and violence against women brought an awareness of the genderbias in international human rights and refugee regimes to state representatives and to international society in general. First, it was necessary to show that the abuses and discrimination suffered by women are widespread and systemic. Second, the "gender" dimension of these abuses needed to be es- tablished (i.e., women suffer particular forms of harm and for particular reasons related to their gender). Thirdly, it was argued that these situations constitute human rights violations, and as such, should give rise to a finding of (gender-related) persecution in the determination of refugee status.

Transnational issue networks on women's rights, human rights and refugees played the key role of introducing new information and concepts in the debate, and of framing the issues in terms of rights and obligations. States' positions can be seen to have evolved progressively over the ten year period between the Nairobi and Beijing conferences. The particular needs of refugee women were first recognized in the 1985 Nairobi Forward Looking Strategies. ${ }^{21}$ At the Vienna conference in 1993, states recognized systemic abuse and discrimination against women as human rights issues. ${ }^{22}$ Then in 1995, the Beijing Platform for Action explicitly called on states to recognize gender-related persecution as a basis for refugee status. ${ }^{23}$ Over this ten year period, state representatives at UN conferences and international society in general became aware of the broad issues of women's human rights and of their particular implications for refugee status determination. Thus, transnational issue networks achieved the goals of agenda-setting and of exerting influence on the positions of states at international conferences.

The UNHCR provided a second "institutional space" in which refugee experts could focus states' attention on the problems of gender bias in refugee regimes. The UNHCR brings together a community of refugee experts working within the agency, with state representatives who direct the activities of the UNHCR as members of its Executive Committee. Matters are presented by the Office of the High Commissioner and other working groups to the Executive Committee which deliberates and draws conclusions meant to both guide the activities of the UNHCR and direct the refugee policy of Mem- ber States. In this manner, the UNHCR has served as a forum for the coordination of states' responses to the issue of gender-related persecution.

In 1985, the High Commissioner for Refugees proposed that the Executive Committee (of state representatives to the UNHCR) adopt a Conclusion recognizing the persecution of women who transgress social mores as a basis for refugee status. Further UNHCR Conclusions, increasingly supportive of a gender-sensitive refugee policy, were adopted at annual sessions of the Executive Committee from 1987 onward. In 1990, the Executive Committee adopted the comprehensive Policy on Refugee Women ${ }^{24}$ developed by experts within the UNHCR. A year later, Guidelines on the Protection of Refugee Women ${ }^{25}$ were made public and Guidelines on Prevention and Response to Sexual Violence Against Refugees ${ }^{26}$ were released in 1995. In 1996, the UNHCR convened a Symposium on GenderBased Persecution. By this time, the UNHCR itself had adopted a strong position in support of an international norm accepting gender-related persecution as a basis for refugee status and encouraged states to develop national gender guidelines. Thus, the UNHCR provided an important "institutional space" in which support could be developed for a new international norm.

International law provided the third international "institutional space" in which the case for accepting genderrelated persecution as a basis for refugee status was advanced. International law establishes standards of state conduct through both treaties and customary international law. States that fail to respect these standards find themselves in violation of international law. Violations of human rights and refugee law, because of the focus of each on the interests of individuals rather than of states, may bring little direct sanction from other states. However, to be shown not to respect human rights is a politically uncomfortable position for most governments in their relations with other states and, for some governments, within the arena of domestic politics. 
While the debate continues over whether UN General Assembly resolutions in themselves contribute to the creation of customary international law, it is agreed that many of the provisions of the 1948 Universal Declaration on Human Rights are established principles of law. The 1993 UN General Assembly Declaration on the Elimination of Violence Against Women, and UN Conference Resolutions at Nairobi, Vienna and Beijing may not yet constitute law in the strict sense, but certainly constitute normative international standards against which violations can be condemned. What is perhaps most relevant to note in these declarations and statements is their use of normative language to prescribe and proscribe the behaviour of all states, not just that of states which participate in their elaboration.

Finally, law has an indirect, but extremely powerful influence on the development of international norms by providing a language and conceptual framework within which to present women's claims for refugee status. It is in this way that retribution for the transgression of a social more (take for example the case of stoning of an "adulteress") can be presented as a human rights issue (wherein international standards are violated), which forms the basis of a claim for refugee status and results in protection by the international community. Similarly, through the use of a legal rights discourse, we have come to understand discrimination as persecution, military rapes as war crimes, and domestic abuse as torture.

\section{The Emergence of a New Norm}

The exclusion of gender-related persecution as a basis for granting refugee status originates in international law. However, the effects of this exclusion were felt at the national level of refugee determination systems, and it is at this level that pressure for change first developed. The campaign for the eradication of the gender-bias in refugee determination procedures was internationalized through three significant processes: the campaigns of transnational issue networks on human rights, refugee and women's rights at international conferences; the efforts of experts working within the UNHCR to coordinate the development of refugee policy among states; and the elaboration of standards in international law. Thus, an international dimension was added to domestic pressure building at the national level for change in refugee determination systems. New policy accepting gender-based persecution was initially adopted at the national level. As some states began developing gender-sensitive refugee policy, pressure increased on states who had not institutionalized the norm to do likewise. A fledgling international norm was born.

In closing, it must be remembered that granting refugee status is only a remedial measure which does not address the underlying problem of gender-related persecution except to the extent that granting refugee status implies condemnation of a situation in the asylum seeker's state of origin. This in turn only affects the situation of women if such a condemnation adds pressure on the state of origin to eliminate the source of persecution. Here, considerations of diplomacy come into play: states tend to be reticent to condemn a political or cultural ally by accepting its citizens as refugees. When refugee status is granted, the implied condemnation itself may have little effect in countries which do not seek to become part of a normative community of liberal democracies. The condemnation can even lead to resentment and unwillingness to comply with the perceived imposition of Western standards.

Nonetheless, refugee systems provide an important, if remedial, measure of protection for individuals whose own states have failed them. A norm accepting gender-related persecution as a basis for refugee status extends this important measure of protection to a class of people who had been unjustly excluded. The introduction to this paper suggested that refugee policy can be considered a rough test of a state's commitment to its human rights pronouncements. Since human rights are inevitably an issue that challenges classic conceptions of sovereignty, one wonders to what extent is state-led progress possible when it is states themselves whose identities are reliant on the principle of sovereignty.

'Just how far will states push the limits of sovereignty? Accepting such claimants as refugees may be the greatest extent of their "intervention" in other counties to protect individuals from human rights abuses. Yet even this is not insignificant, for at least it reveals a tension between states' respect for sovereignty and their respect for international human rights standards. Perhaps more than students of international relations give them credit, states know that they operate in both a system of states and in an international human society.

\section{Notes}

1. Guidelines on Women Refugee Claimants Fearing Gender-Related Persecution, issued by the Chairperson Pursuant to Section 65(3) of the Immigration Act, IRB, Ottawa, 9 March 1993.

2. Gender Guidelines: Considerations for Asylum Officers Adjudicating Asylum Claims From Women, Memorandum of 26 May 1995 from Phyllis Coven, Office of International Affairs, to all INS Asylum Officers and Headquarters Coordinators; and Guidelines on Gender Issues for Decision Makers: Refugee and Humanitarian Visa Applicants, Department of Immigration and Multicultural Affairs, Australia, July 1996.

3. While this article will refer to the development of an international norm, evidence of this development is Westernbiased as it is primarily in these countries that refugee status determination procedures apply the criteria of the 1951 United Nations Convention relating to the Status of Refugees (UN Refugee Convention), 189 U.N.T.S. 2545, entered into force 22 April, 1954. Evidence of more broadly-based international support for the norm is found in UNHCR EXCOM Conclusions and UN conference declarations on refugee women.

4. Through the indirect methods of travel restrictions, "port of first entry" requirements and "safe country" policies, many States have been tightening restrictions for entry as refugees. See Barbara Harrell Bond, "The Evolution of Solutions: A 
History of Refugee Policy," Oxford International Review VII, no. 3 (Summer 1996): 2-6.

5. A transnational issue networks is defined as "the set of relevant actors working internationally in an issue who are bound together by shared values, a common discourse, and dense exchanges of information and services." Kathryn Sikkink, "Transnational Networks on Violence Against Women," Paper prepared for presentation at the XIX International Congress of the Latin American Studies Association, Washington, DC, September 28-30, 1995, 3. Examples of transnational issue networks would include the international environmental lobby, the international human rights movement, international nuclear disarmament campaigns, etc.

6. European Parliament Document 1-112/ 84, Resolution adopted April 13, 1984.

7. "Conclusion on Refugee Women and International Protection" (no. 39), UNHCR EXCOM, Report of the 36th Session: UN Doc. A/AC.96/673, para. $115(4)(k)$.

8. See the case of "Nada," a Saudi woman, who was harassed by the "religious police" for acting contrary to the restrictions imposed on women, and the case of "Dularie," a Trinidadian woman who was fleeing severe domestic abuse from which she did not receive protection by the authorities. These cases are discussed in Audrey Macklin, "Refugee Women and the Imperative of Categories," $\mathrm{Hu}$ man Rights Quarterly 17 (1995): 215-17.

9. Estanislao Oziewicz, "Canada Not Planning to Widen Refugee Rules to Cover Sex Bias," Globe and Mail, Toronto, 16 January 1993, A9.

10. Nurjehan Mawani, "Introduction to the Immigration and Refugee Board Guidelines on Gender-Related Persecution," International Journal of Refugee Law 5, no. 2 (1993): 240-47.

11. Canadian Charter of Rights and Freedoms, Part I of the Constitution Act 1982, being Schedule B of the Canada Act 1982 (U.K.), 1982 c.11.

12. Hossie, Linda "For Women, Oppression is Often a Way of Life," Globe and Mail, Toronto, 5 February 1993, A1.

13. Anne Leiss and Ruby Boesjes, Female Asylum Seekers: A Comparative Study Concerning Policy and Jurisprudence in The Netherlands, Germany, France, The United Kingdom, Also Dealing Summarily With Belgium and Canada, (Amsterdam: Dutch Refugee Council, 1994), 93.

14. The Refugee Council, Factfile: Women Refugees, London, November 1996, 4.

15. Leiss and Boesjes, Female Asylum Seekers, 95.
16. See chapter 3, section 1 of the Aliens Act $(1989,529)$ as amended by Act $(1996$, 1379), adopted 12 December 1996, entered into force 1 January, 1997.

17. Isabelle Daoust and Kristina Folkelius, "Developments: UNHCRSymposium on Gender-Based Persecution," International Journal of Refugee Law 8 no.1 (1996): 180.

18. Leiss and Boesjes, Female Asylum Seekers, 94.

19. Ibid., 95.

20. Daoust and Folkelius, "Developments," 181.

21. Nairobi: Forward Looking Strategies for the Advancement of Women, paras. 298-89, UN Doc. A/CONF.116/28/Rev.1 (1985).

22. UN World Conference on Human Rights: Vienna Declaration and Programme of Action, adopted 25 June 1993, UN Doc. A/ CONF.157/24, para. 18.

23. UN Fourth Conference on Women, Beijing Declaration and Platform for Action, UN Doc. A/CONF.177/20 (1995), paras. 147 (h), (i).

24. UNHCR EXCOM, Report of the 39th Session: UN Doc. A/AC.96/754.

25. UNHCR, UN Doc. EC/SCP/67, Geneva, July 1991.

26. UNHCR, Geneva, 8 March 1995. ם

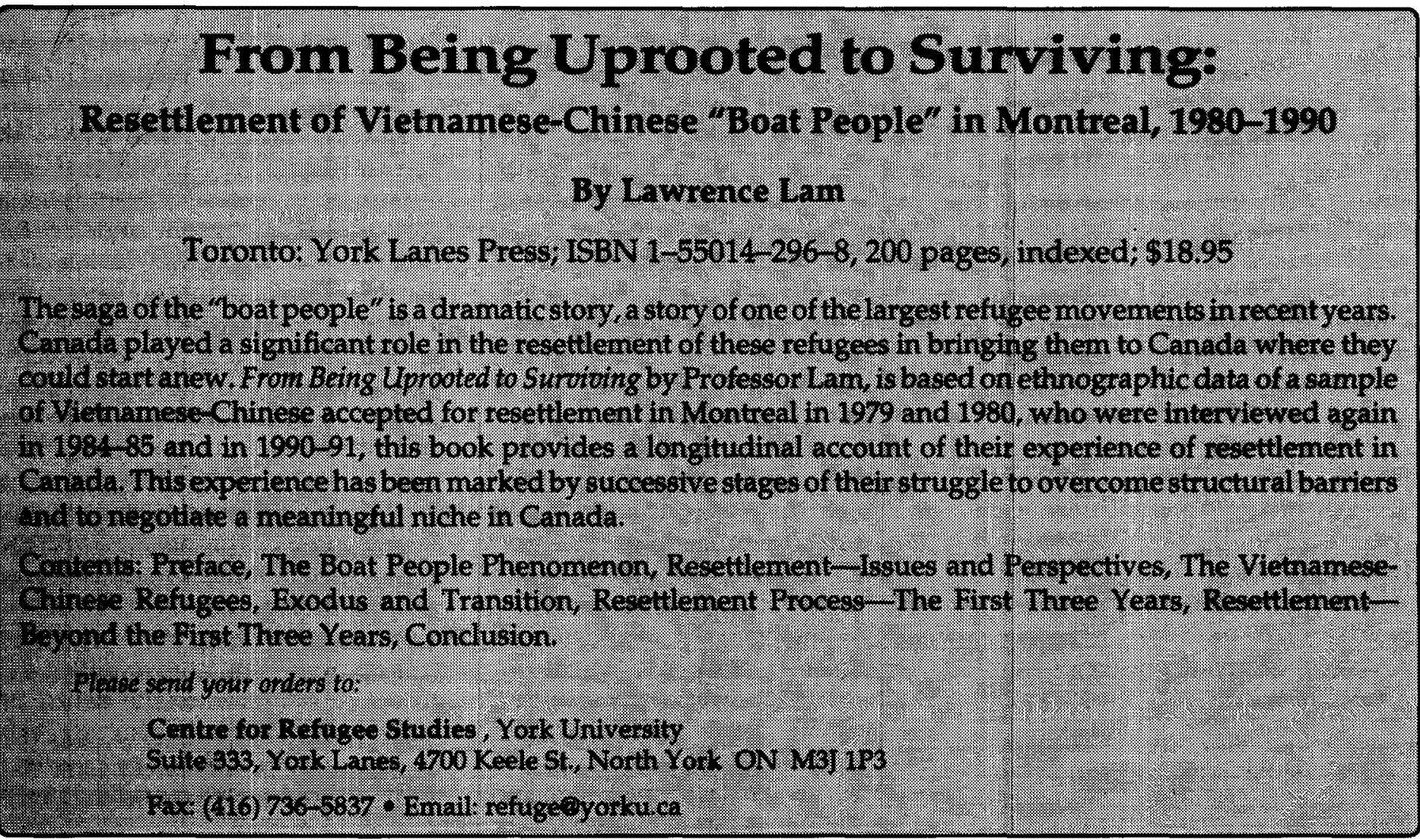

Refuge, Vol. 16, No. 4 (October 1997) 